\title{
Antibacterial Activity Analysis of Hydroxyapatite Based Materials with Fluorine and Silver
}

\section{Análisis de la Actividad Antibacteriana de Materiales a Base de Hidroxiapatita con Flúor y Plata}

\author{
V. González-Torres'; E. Hernández-Guevara²; N. A. Castillo-Martínez'; M. Rosales-Aguilar'; G. C. Díaz-Trujillo² \\ 'Facultad de Ciencias de la Salud de la Universidad Autónoma de Baja California \\ 2Facultad de Ciencias Químicas e Ingeniería de la Universidad Autónoma de Baja California \\ ${ }^{3}$ Facultad de Medicina y Psicología de la Universidad Autónoma de Baja California
}

\begin{abstract}
This investigation aims to evaluate the antibacterial activity of nanostructured hydroxyapatite based materials doped with silver and fluorine, to be used as a biomaterial with antibacterial activity. Four different formulations were prepared by combustion method: hydroxyapatite, hydroxyapatite-fluorine, hydroxyapatite-silver-fluorine and hydroxyapatite-silver, with $2 \%$ of the doping agents. X-ray diffraction technique was used to determine the mineralogy, identifying the presence of $\mathrm{Ca}_{5}\left(\mathrm{PO}_{4}\right)_{3} \mathrm{OH}, \mathrm{Ca}_{2} \mathrm{P}_{2} \mathrm{O}_{7}, \mathrm{Ag}_{3} \mathrm{PO}_{4}, \mathrm{AgCa}_{10}\left(\mathrm{PO}_{4}\right)_{7} \mathrm{Ca}_{5}\left(\mathrm{PO}_{4}\right)_{3} \mathrm{~F}$ and CaF 2 phases for the studied samples. Scanning electron microscopy was used to study the morphological structure and it showed homogeneous crystallization of the hydroxyapatite and the inclusion of dopant agents. The antibacterial activity was determined using a modified inhibition test zone to observe if the bacteria (E. faecalis) was susceptible to the antimicrobial agent by the appearance of the zone of inhibition on the agar plate. Both the hydroxyapatite-silver and the hydroxyapatite-silver-fluorine materials generated an inhibition zone. It was possible to determine the minimum inhibitory concentration needed to kill most viable organisms after 48 hours of incubation using the broth microdilution method, resulting in $75 \mu \mathrm{g} / \mathrm{ml}$ and $200 \mu \mathrm{g} / \mathrm{ml}$ for the hydroxyapatite-silver and the hydroxyapatite-silver-fluorine formulation, respectively. These materials could be used for the development of new biomaterials that can be used in dental applications.
\end{abstract}

KEYWORDS: hydroxyapatite; antibacterial; silver 


\section{RESUMEN}

El objetivo de esta investigación es analizar la actividad antibacteriana de materiales nanoestructurados a base de hidroxiapatita con iones de flúor y plata que le confieran características particulares para que pueda ser utilizado como un biomaterial con actividad antimicrobiana. Se realizaron cuatro formulaciones distintas: hidroxiapatita, hidroxiapatita-flúor, hidroxiapatita-plata-flúor e hidroxiapatita-plata con un $2 \%$ de los agentes dopantes. La síntesis del material se realizó a través del método de combustión. La caracterización mineral se realizó a través de difracción de rayos $\mathrm{X}$ identificando las siguientes fases en las diversas formulaciones: $\mathrm{Ca}_{5}\left(\mathrm{PO}_{4}\right)_{3} \mathrm{OH}_{2} \mathrm{Ca}_{2} \mathrm{P}_{2} \mathrm{O}_{7}, \mathrm{Ag}_{3} \mathrm{PO}_{4}$, $\mathrm{AgCa}_{10}\left(\mathrm{PO}_{4}\right)_{7} \mathrm{Ca}_{5}\left(\mathrm{PO}_{4}\right)_{3} \mathrm{~F}$ and $\mathrm{CaF}_{2}$. La estructura morfológica se analizó a través de microscopía electrónica de barrido que muestra la formación de estructuras compactas, presencia de cristales y la incrustación de flúor y plata. Se analizó la actividad antimicrobiana utilizando una prueba modificada para la observación del halo de inhibición, encontrándose solamente que los materiales que contenían plata-flúor y plata generaron dicho halo de inhibición. Por otra parte, usando la prueba de microdilución en pozo se encontró que la concentración mínima inhibitoria para el material de HA-Ag fue de $75 \mu \mathrm{g} / \mathrm{ml}$ y para el material de HA-Ag-F fue de $200 \mu \mathrm{g} / \mathrm{ml}$, después de 48 horas de incubación utilizando E. faecalis.

PALABRAS CLAVE: hidroxiapatita; antibacterial; plata

\section{Corresponding author}

TO: Verónica González Torres

INSTITUTION: Facultad de Ciencias de la Salud

de la Universidad Autónoma de Baja California

ADDRESS: Blvd. Universitario \#1000, Unidad Valle de las

Palmas, C. P. 21500, Tijuana, Baja California, México

E-MAIL: vgonzalezt@uabc.edu.mx

\section{Received:}

14 October 2020

Accepted:

25 January 2021 


\section{INTRODUCTION}

Hydroxyapatite $(\mathrm{HA}), \mathrm{Ca}_{5}\left(\mathrm{PO}_{4}\right)_{3}(\mathrm{OH})$, is an inorganic calcium phosphate compound present in nature including the human body ${ }^{[1]}{ }^{[2]}$. Synthetic hydroxyapatite is a biomaterial because it is biocompatible with human tissues and has bioactive properties. Therefore, Nayak ${ }^{[3]}$ says that "it is widely used in various biomedical applications, mainly in orthopedics and dentistry” (p903).

Incorporating dopants into minerals can greatly modify the mineral characteristics related to the crystallization degree or improvement of stability ${ }^{[4]}$. Adding fluorine to HA produces fluorohydroxyapatite, which is more chemically stable and has a lower solubility than HA alone ${ }^{[5]}$. HA's cation exchange rate is very high with heavy metals or ions like $\mathrm{Pb}^{2+}, \mathrm{Ca}^{2+}, \mathrm{Cu}^{2+}$, $\mathrm{Mn}^{2+}, \mathrm{Co}^{2+}$ and $\mathrm{Ag}^{+}$among others ${ }^{[6]}$. Metallic or ionic silver compounds have been used in a wide variety of products due to their antibacterial activity (including bacteria, viruses and fungi) ${ }^{[4][7][8]}$. According to Kolmas et al. [9], silver has "strong antibacterial properties of an exceptionally broad spectrum” (p3-4).

At low concentrations, silver cations are microcidal and can be used to treat burns, wounds, ulcers or as coatings of medical devices or implants because it delays the microbial biofilm development ${ }^{[10]}$. It is important to calculate the silver content in doped hydroxyapatite based materials, according to Kolmas et al. "9] "since it should be high enough to be able to effectively fight microorganism, while at the same time it should also be limited in order that it does not adversely affect the condition of mammalian tissues" (p5). The antimicrobial effect of silver nanostructures material systems occurs in different ways in the microbial cell, such as damage to the cell membrane by destabilization and cell lysis, damage to the subcellular microbial structure, caused by free $\mathrm{Ag}^{+}$ions and generation of reactive oxygen species (ROS) or inactivation of proteins, enzymes and nucleotides, as well as the modification of microbial signal transduction pathways ${ }^{[11][12]}$. The antibacterial effects of silver compounds shows less toxicity in human cells by altering metabolic pathways unique to bacteria and inducing apoptosis dependent on particle size ${ }^{[13]}$.

Among all the methods or techniques used to prepare HA, combustion has its advantages because it produces nanocrystalline powders with specific characteristics depending on the combustion heat and gas evolution ${ }^{[4]}$.

According to Clinical and Laboratory Standards Institute (CLSI) standards for antimicrobial susceptibility test, there are several ways for determining bactericidal activity of antimicrobial agents such a disk diffusion, broth dilution and agar dilution that measures the inhibitory activity (MIC) of an antimicrobial agent ${ }^{[14]}{ }^{[15]}$. For routine determinations, the microdilution method is preferred.

Enterocuccus faecalis (E. faecalis) is a microbial indicator of peri-implantitis and endodontic failure, since the bacteria has been found in the tooth root and the surrounding tissue after implant placement ${ }^{[16][17]}$. Confocal microscopy studies have demonstrated its persistence in the periapical spaces and the root cementum ${ }^{[18]}$.

The aim of the present study is to investigate the antibacterial activity of hydroxyapatite and hydroxyapatite based materials doped with silver and fluorine against $\mathrm{E}$. faecalis since it is the most prominent microorganism involved in persistent infections after root canal therapy ${ }^{[18]}$.

\section{MATERIALS AND METHODS}

\section{a) Hydroxyapatite based material preparation}

In order to prepare the hydroxyapatite based materials with and without silver and fluorine, calcium nitrate $\left(\mathrm{Ca}\left(\mathrm{NO}_{3}\right)_{2}\right)$, ammonium phosphate dibasic $\left(\left(\mathrm{NH}_{4}\right)_{2} \mathrm{HPO}_{4}\right)$, silver trifluoroacetate 
$\left(\mathrm{CaF}_{3} \mathrm{O}_{2} \mathrm{Ag}\right)$, calcium fluoride $\left(\mathrm{CaF}_{2}\right)$ and silver nitrate $\left(\mathrm{AgNO}_{3}\right)$ were used as precursors. Urea $\left(\mathrm{CO}\left(\mathrm{NH}_{2}\right)_{2}\right)$ was used as fuel.

Four different hydroxyapatite materials were formulated: hydroxyapatite (HA), hydroxyapatite with fluorine (HA-F), hydroxyapatite with silver and fluorine (HA-Ag-F), and hydroxyapatite with silver (HA-Ag). The synthesis of 5 grams of all four HA materials was performed using the combustion method. For all the formulations a 1.67 ratio of $\mathrm{Ca} / \mathrm{P}$ was used, as for the HA-F, HA-Ag-F and HA-Ag formulations, $2 \%$ of the doping agents were used. Every formulation received two thermal treatments, the first one up to $600^{\circ} \mathrm{C} / 240$ min with a heating speed of $5^{\circ} \mathrm{C} / \mathrm{min}$, and the second one up to $900^{\circ} \mathrm{C} / 240 \mathrm{~min}$ at same conditions.

\section{b) Characterization}

The powder samples obtained were characterized by the X-ray powder diffraction (XDR) method (Bruker X-ray Diffraction D8 Advance diffractometer) with $\mathrm{Cu} \mathrm{K} \alpha 1$. Data were collected over $\theta$ range of $10-70^{\circ}$. The final materials' surface was observed by using scanning electron microscopy (SEM) (JEOL JSM 7600F microscope).

\section{c) Antibacterial evaluation}

The materials' antibacterial effects were tested against ATCC reference and clinical microbial strains (E. faecalis ATCC 29212). First, a modified inhibition test zone (Kirby-Bauer Test) was performed to observe if the bacteria were susceptible to the antimicrobial agent by the dimension of the inhibition zone on the agar plate. E. faecalis ATCC 29212 was grown in pure culture. Using a sterile swab, a suspension of the axenic culture was spread evenly over the surface of a MuellerHinton agar plate. Instead of using a paper disk as indicated in the CLSI guide, each material was applied to the center of a different agar plate. After 24 hours of incubation at $37^{\circ} \mathrm{C}$, the plates were observed to see the inhibition around the test product. A control plate was also performed.

The broth microdilution method (Muller-Hinton broth) was used to determine the minimum inhibitory concentration. Dilutions of the materials were prepared freshly for each experiment. Microbial suspensions of $5 \times 105$ colony-forming unit (CFU)/ml obtained from 18 to 20 hours bacterial cultures developed on solid media were used.

\section{RESULTS AND DISCUSSION}

\section{a) Characterization}

All materials obtained were homogeneous powders. The mineralogical XDR analysis of the materials identified hydroxyapatite as a primary phase and various structures and other types of phosphates. Table 1 shows the crystalline phases present in the studied samples and their respective XDR identification card, obtained by XDR.

The XDR patterns of the hydroxyapatite based materials are shown in Figures 1 to 4. All figures present two diffraction patterns, because two different ther-

TABLE 1. XDR Crystalline phases.

\begin{tabular}{|c|c|c|}
\hline Formulation & Crystalline phases & XDR card \\
\hline HA & $\begin{array}{l}\mathrm{Ca}_{5}\left(\mathrm{PO}_{4}\right)_{3} \mathrm{OH} \\
\alpha-\mathrm{Ca}_{2} \mathrm{P}_{2} \mathrm{O}_{7} \\
\beta-\mathrm{Ca}_{2} \mathrm{P}_{2} \mathrm{O}_{7}\end{array}$ & $\begin{array}{l}000090432 \\
000090345 \\
000200024\end{array}$ \\
\hline HA-F & $\begin{array}{l}\alpha \mathrm{Ca}_{2} \mathrm{P}_{2} \mathrm{O}_{7} \\
\mathrm{Ca}_{5}\left(\mathrm{PO}_{4}\right)_{3} \mathrm{~F} \\
\mathrm{CaF}_{2}\end{array}$ & $\begin{array}{l}000090345 \\
000150876 \\
000040864\end{array}$ \\
\hline HA-Ag-F & $\begin{array}{l}\beta-\mathrm{Ca}_{2} \mathrm{P}_{2} \mathrm{O}_{7} \\
\mathrm{Ag}_{3} \mathrm{PO}_{4}\end{array}$ & $\begin{array}{l}000200024 \\
010897399\end{array}$ \\
\hline HA-Ag & $\begin{array}{l}\mathrm{Ca}_{5}\left(\mathrm{PO}_{4}\right) \\
\mathrm{Ag}_{3} \mathrm{PO}_{4} \\
\mathrm{Ag}_{4} \mathrm{P}_{2} \mathrm{O}_{7} \\
\mathrm{Ag} \\
\mathrm{AgCa}_{10}\left(\mathrm{PO}_{4}\right)_{7}\end{array}$ & $\begin{array}{l}000090432 \\
010897399 \\
000370187 \\
010893722 \\
000541098\end{array}$ \\
\hline
\end{tabular}




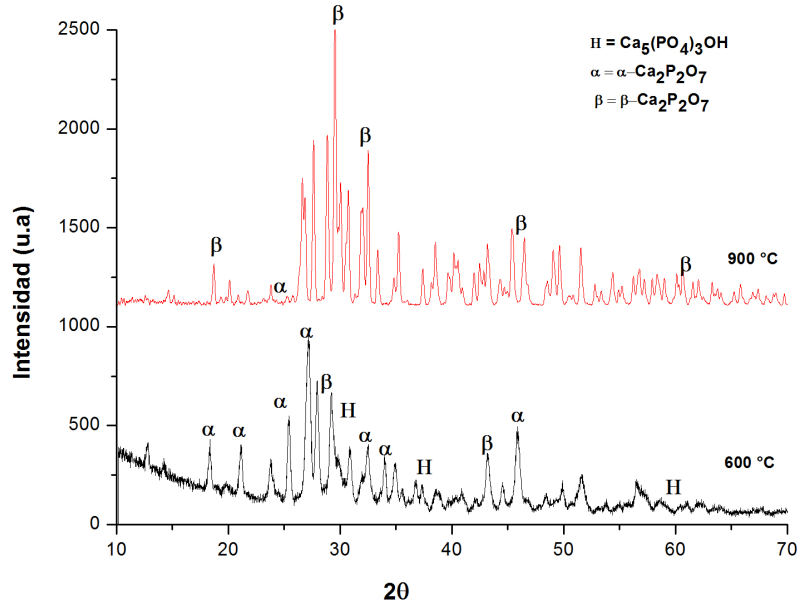

FIGURE 1. Hydroxyapatite

(HA) XDR diffraction pattern.

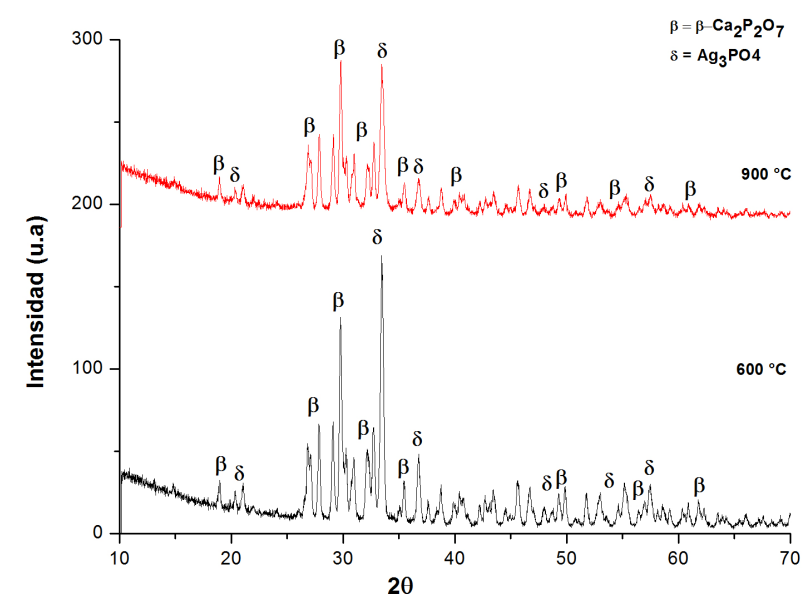

FIGURE 3. Hydroxyapatite with silver and fluorine (HA-Ag-F) XDR diffraction pattern.

mal treatments were applied, one at $600^{\circ} \mathrm{C}$ and the other at $900^{\circ} \mathrm{C}$. Different heat treatments were applied in order to evaluate the thermal effect on the crystallization phase. All XDR diffraction patterns were obtained from the different materials' powder.

The heat-treated samples at $900^{\circ} \mathrm{C}$, show patterns that have better definition, in terms of crystallization.

Figure 1 shows the hydroxyapatite formulation XRD patterns, that closely matches the regular hydroxyapatite pattern. It shows the presence of $\mathrm{Ca}_{5}\left(\mathrm{PO}_{4}\right)_{3} \mathrm{OH}$ as main phase; also $\alpha-\mathrm{Ca}_{2} \mathrm{P}_{2} \mathrm{O}_{7}$, and $\beta-\mathrm{Ca}_{2} \mathrm{P}_{2} \mathrm{O}_{7}$ as second-

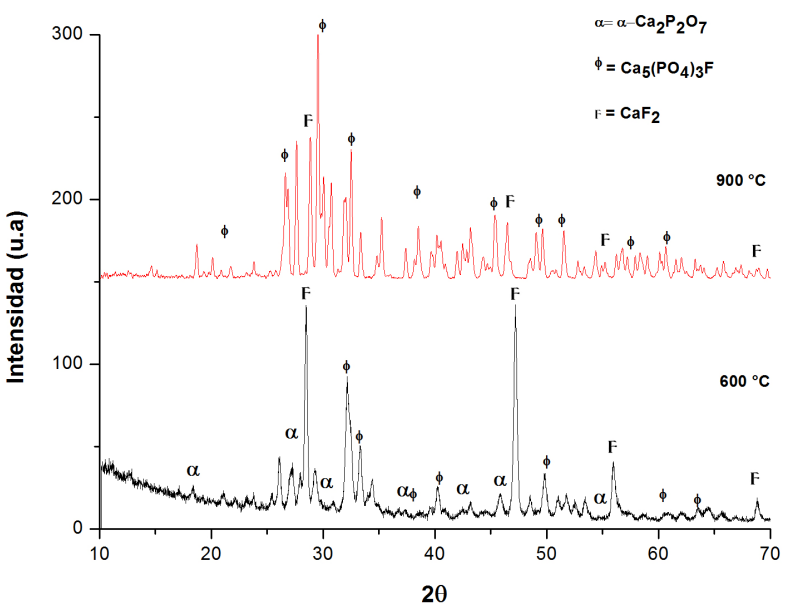

FIGURE 2. Hydroxyapatite with fluorine (HA-F) XDR diffraction pattern.

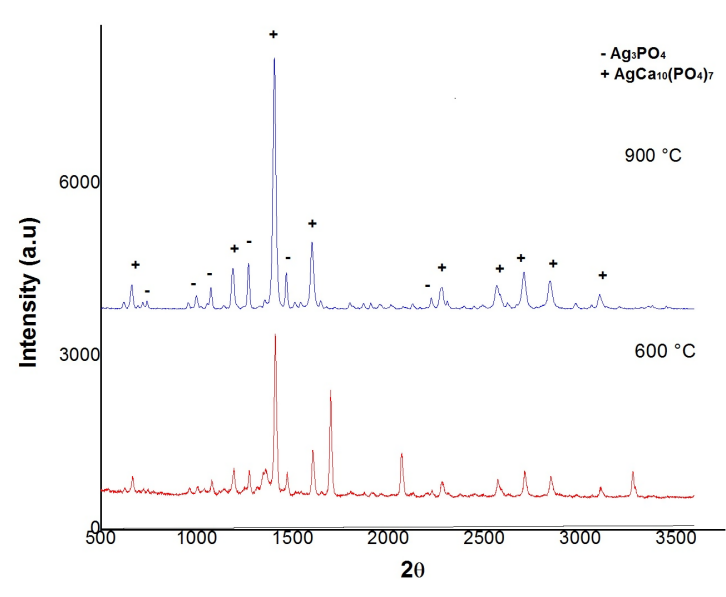

FIGURE 4. Hydroxyapatite with silver (HA-Ag) XDR diffraction pattern.

ary phases. Figure 2 shows the hydroxyapatite fluorine material diffraction patterns, where fluorapatite $\left(\mathrm{Ca}_{5}\left(\mathrm{PO}_{4}\right)_{3} \mathrm{~F}\right)$ is the main phase, and $\alpha-\mathrm{Ca}_{2} \mathrm{P}_{2} \mathrm{O}_{7}$ and $\mathrm{CaF}_{2}$ are secondary phases.

Figure 3 shows the hydroxyapatite with silver and fluorine material diffraction patterns. As can be observed, the peaks correspond to $\mathrm{Ag}_{3} \mathrm{PO}_{4}$ and $\beta-\mathrm{Ca}_{2} \mathrm{P}_{2} \mathrm{O}_{7}$, the $\mathrm{CaF}_{2}$ peaks are very weak at $2 \Theta \sim 29^{\circ}$. Figure 4 shows the hydroxyapatite silver diffraction patterns in which $\mathrm{Ag}, \mathrm{Ag}_{3} \mathrm{PO}_{4}, \mathrm{Ag}_{4} \mathrm{PO}_{7}$ and $\mathrm{AgCa}_{10}\left(\mathrm{PO}_{4}\right)_{7}$ are present. This material is the one with the highest number of crystalline phases. 


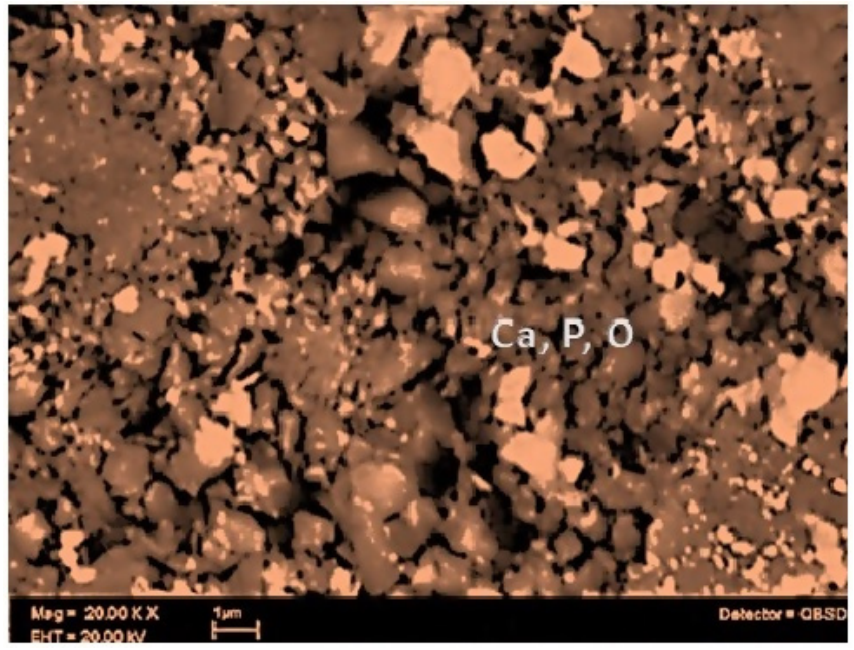

FIGURE 5. SEM micrograph of

Hydroxyapatite material (HA).

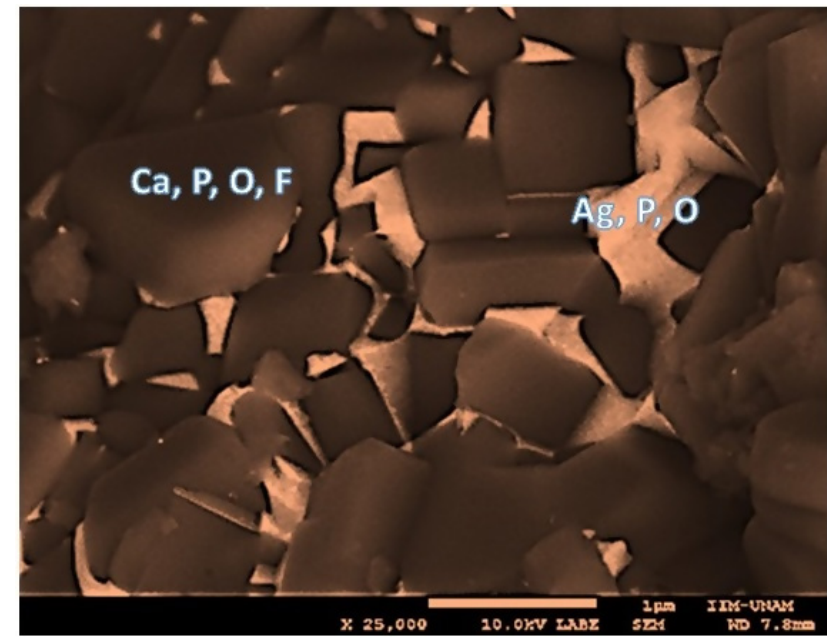

FIGURE 7. SEM micrograph of

Hydroxyapatite-silver-fluorine material (HA-Ag-F).

Figures 5 to 8 show the scanning electron microscopy (SEM) images of the hydroxyapatite based materials surface structures with and without silver and/or fluorine at $900^{\circ} \mathrm{C}$, by microanalysis of secondary electrons of energy dispersive X-ray spectroscopy (EDS).

A homogeneous crystallization is observed for the HA based material with and without silver and/or fluorine. The brighter zones correspond to silver and fluorine ${ }^{[4]}$. The grain size of each material happens to be in the nanometric scale.

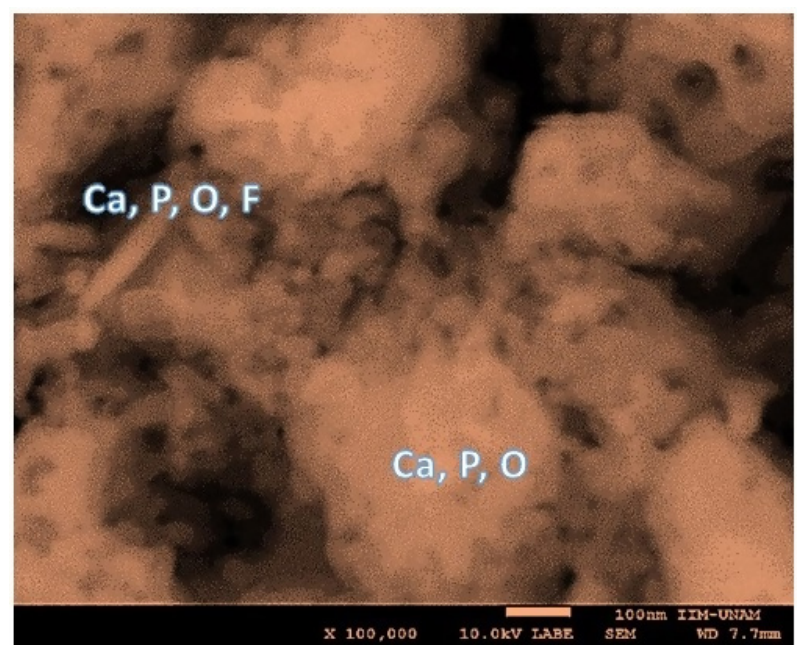

FIGURE 6. SEM micrograph of

Hydroxyapatite-fluorine material (HA-F).

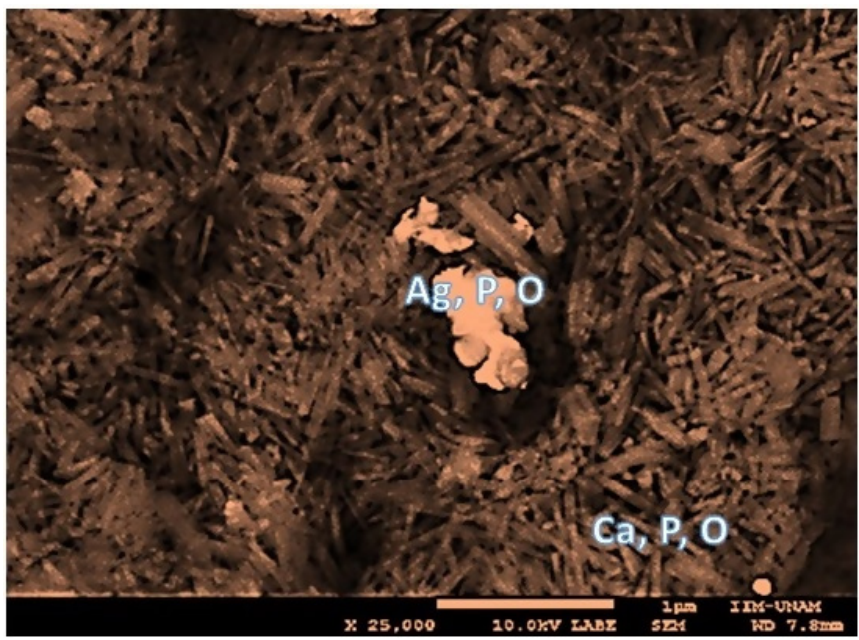

FIGURE 8. SEM micrograph of

Hydroxyapatite-silver material (HA-Ag).

Figure 5 shows the surface analysis of HA material in which a matrix formed mainly by grains composed of $\mathrm{Ca}, \mathrm{P}$ and $\mathrm{O}$, can be observed. Figure 6 shows the surface of the HA-F material in which two zones can be observed, one containing crystals ( $\mathrm{Ca}, \mathrm{P}, \mathrm{O}$, and $\mathrm{F}$ ) and the other with circular shaped particles (Ca, $\mathrm{P}$, and $\mathrm{O}$ ).

The HA-Ag-F material has two defined areas, a crystalline one, composed of $\mathrm{Ca}, \mathrm{P}, \mathrm{O}$ and $\mathrm{F}$, and a second interface, between the grain boundaries, composed of Ag, $\mathrm{P}$ and $\mathrm{O}$ (Figure 7). Figure 8 shows the surface of 
the HA-Ag material in which it is possible to observe a predominant homogeneous crystallization phase (Ca, $\mathrm{P}$ and $\mathrm{O}$ ), and a clearly identifiable secondary phase (Ag, $\mathrm{P}$ and $\mathrm{O}$ ).

b) Antibacterial activity evaluation

After 48 hours of incubation, the modified inhibition test zone showed that HA and HA-F materials did not present antibacterial activity due to the absence of the inhibition zone. Both HA-Ag-F and HA-Ag materials generated an inhibition zone; demonstrating their antibacterial activity. HA-Ag material showed a bigger inhibition zone in comparison to HA-Ag-F. Figure 9 shows the inhibition zones formed by the materials after 48 hours of incubation. After seven days, the HA-Ag inhibition zone grew more than the HA-Ag-F, whereas HA and HA-F did not develop an inhibition zone. Figure 10 shows the inhibition zones maintained after seven days.

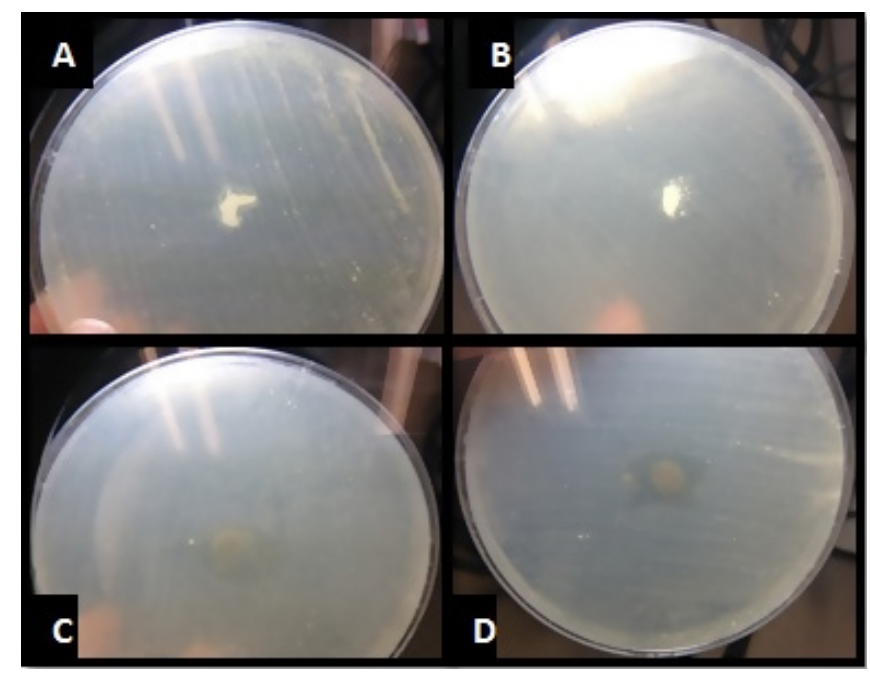

FIGURE 9. Inhibition zones formed after $\mathbf{4 8}$ hours of incubation of A) HA material, B) HA-F material, C) HA-Ag-F material, D) HA-Ag material in E. faecalis.

The minimum inhibitory concentration for the silver-doped hydroxyapatite (HA-Ag) material needed to kill most of the viable organism (E. faecalis) after 24 hours of incubation was $75 \mu \mathrm{g} / \mathrm{ml}$, and $200 \mu \mathrm{g} / \mathrm{ml}$ for the silver and fluorine-doped hydroxyapatite (HA-Ag-F) respectively. Figure 11 shows the microdilution trays for the HA-Ag formulation and Figure 12 shows the results for the HA-Ag-F formulation.

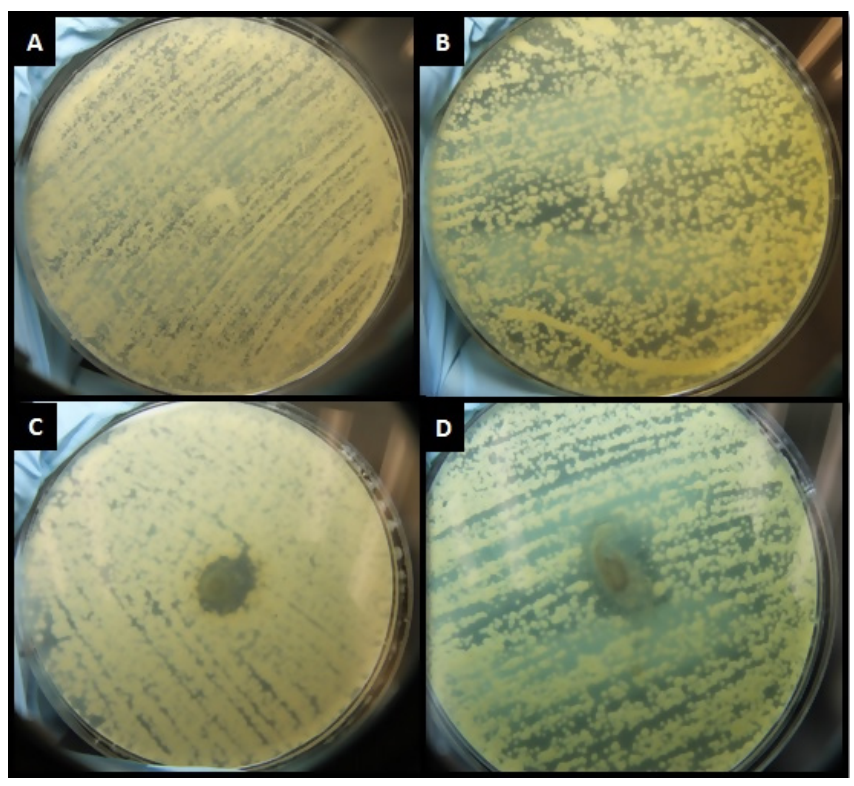

FIGURE 10. Inhibition zones after seven days of incubation of A) HA material, B) HA-F material, C) HA-Ag-F material, D) HA-Ag material in E. faecalis.

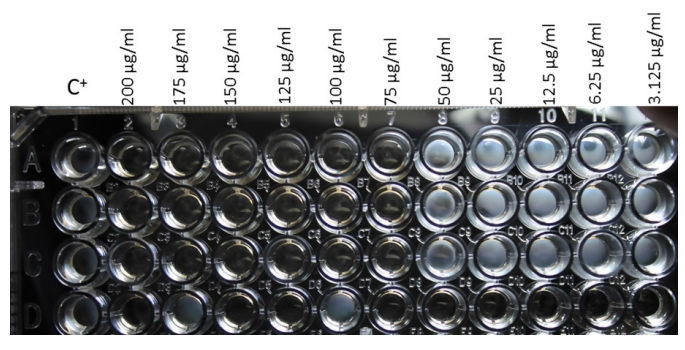

FIGURE 11. HA-Ag minimum inhibitory concentration results in E. faecalis.

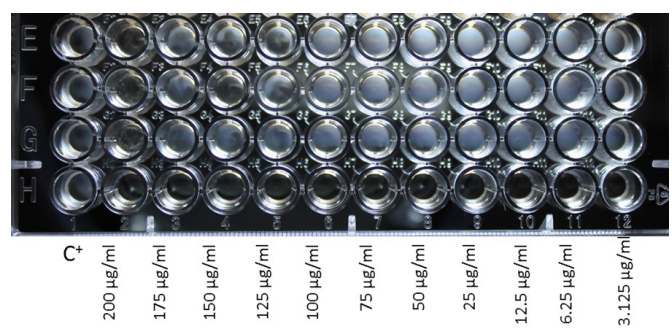

FIGURE 12. HA-Ag-F minimum inhibitory concentration results in $\mathrm{E}$. faecalis. 


\section{CONCLUSIONS}

The aim of this investigation was to evaluate the antibacterial activity of nanostructured hydroxyapatite based materials doped with silver and/or fluorine. It was demonstrated that the hydroxyapatite and hydroxyapatite with fluorine formulations did not form an inhibition zone due to its lack of antibacterial properties, as it was expected because neither of these formulations contained antibacterial dopant agents. It was demonstrated that the hydroxyapatite with silver and the hydroxyapatite with silver and fluorine formulations have antibacterial properties; they inhibited the E. faecalis bacteria's growth. The minimum inhibitory concentration of the hydroxyapatite with silver formulation needed to kill most viable organism after 24 hours of incubation was $75 \mu \mathrm{g} / \mathrm{ml}$, and $200 \mu \mathrm{g} / \mathrm{ml}$ for the silver and fluorine-doped hydroxyapatite formulation. It is recommended to perform more tests to determine if the materials have a bacteriostatic or bactericidal effect.

The hydroxyapatite with silver formulation had the highest antibacterial activity when compared to the silver and fluorine-doped hydroxyapatite formulation, possibly due to the lower amount of silver contained in this last formulation. This is why, new formulations are recommended, where the amount of silver is higher, all the while maintaining the presence of fluorine in the hydroxyapatite matrix since its presence lower the hydroxyapatite solubility and therefore its deionization, which in turn allows the tooth to not demineralize.
HA-Ag formulation shows activity in E. faecalis and a potential use in the treatment for root canals or in other dental applications due to its antibacterial activity.

According to the available literature, these materials could be used to develop new biomaterials that in effect can be use in the health field, particularly in dentistry.

\section{AUTHOR CONTRIBUTIONS}

V.G.T. conceived the idea, carried out the formulation and synthesis of the hydroxyapatite based materials doped with silver and fluorine, contributed; Contributed to perform the materials physical and chemical properties analysis by X-ray Diffraction and Scanning Electron Microscopy. Contributed to carry out the antibacterial evaluation experiments. Took the lead in writing the manuscript. E.H.G. designed and performed the antibacterial evaluation experiments. N.A.C.M. contributed to carry out the antibacterial evaluation experiments and to the interpretation of the antibacterial evaluation experiments results and writing of the manuscript. M.R.A. contributed to perform data processing and writing of the manuscript. G.C.D.T. contributed to carry out the formulation and synthesis of the materials; performed the hydroxyapatite based materials physical and chemical properties analysis by X-ray Diffraction and Scanning Electron Microscopy. Performed data processing and writing of the manuscript. 


\section{REFERENCES}

[1] Tas AC. Combustion synthesis of calcium phosphate bioceramic powders. J Eur Ceram Soc [Internet]. 2000;20(14-15):2389-2394. Available from: https://doi.org/10.1016/S0955-2219(00)00129-1

[2] Markovic M, Fowler BO, Tung MS. Preparation and Comprehensive Characterization of a Calcium Hydroxyapatite Reference Material. J Res Natl Inst Stand Technol [Internet]. 2004;109(6):553-68. Available from: http://dx.doi.org/10.6028/jres.109.042

[3] Nayak AK. Hydroxyapatite synthesis methodologies: an overview. Int J ChemTech Res. 2010; 2(2): 903-907.

[4] González-Torres V, Méndez-Sánchez ER, Gaitán-Cepeda LA, et al. Characterization and Biocompatibility Evaluation of Hydroxyapatite Doped with Silver and/or Fluorine. Adv Sci Tech [Internet]. 2014;96:27-32. Available from: https://doi.org/10.4028/www.scientific.net/AST.96.27

[5] Robinson C, Shore RC, Brookes SJ, et al. The Chemistry of Enamel Caries. Crit Rev Oral Bio Med [Internet]. 2000;11(4):481-495. Available from: https://doi.org/10.1177/10454411000110040601

[6] Kim TN, Feng QL, Kim JO, et al. Antimicrobial effects of metal ions (Ag+. $\mathrm{Cu} 2+, \mathrm{Zn2+})$ in hydroxyapatite. J Mater Sci Mater Med [Internet]. 1998;9(3):129-34. Available from: https://doi.org/10.1023/A:1008811501734

[7] Kawashita M, Tsuneyama S, Miyaji F, et al. Antibacterial silvercontaining silica glass prepared by sol-gel method. Biomaterials [Internet]. 2000;21(4):393-98. Available from: https://doi.org/10.1016/S0142-9612(99)00201-X

[8] Bai X, More K, Rouleau CM, Rabiei A. Functionally graded hydroxyapatite coatings doped with antibacterial components. Acta Biomater [Internet]. 2010;6(6):2264-2273. Available from: https://doi.org/10.1016/j.actbio.2009.12.002

[9] Kolmas J, Groszyk E, Kwiatkowska-Różycka D. Substituted Hydroxyapatites with Antibacterial Properties. BioMed Res Int [Internet]. 2014;2014:1-15. Available from: https://doi.org/10.1155/2014/178123
[10] Silver S. Bacterial silver resistance: molecular biology and uses and misuses of silver compounds. FEMS Microbiol Rev [Internet]. 2006;27(2-3):341-53. Available from: https://doi.org/10.1016/S0168-6445(03)00047-0

[11] Burdusel, A-C, Gherasim O, Grumezescu AM, et al. Biomedical Applications of Silver Nanoparticles: An Up-to-Date Overview. Nanomaterials [Internet]. 2018; 8(9):681. Available from: https://doi.org/10.3390/nano8090681

[12] Durán N, Durán M, de Jesús MB, et al. Silver nanoparticles: A new vie won mechanistic aspects on antimicrobial activity. NMB [Internet]. 2016;12(3):789-799. Available from: https://doi.org/10.1016/j.nano.2015.11.016

[13] Salleh A, Naomi R, Utami ND, et al. The Potential of Silver Nanoparticles for Antiviral and Antibacterial Applications: A Mechanism of Action. Nanomaterials [Internet]. 2020;10(8): 1566. Available from: https://doi.org/10.3390/nano10081566

[14] National Committee for Clinical Laboratory Standards. Methods for determining bactericidal activity of antimicrobial agents: approved guideline. Wayne, PA: National Committee for Clinical Laboratory Standards; 1999.

[15] Clinical and Laboratory Standards Institute. Performance standards for antimicrobial disk susceptibility tests. 13th ed. Wayne, PA: National Committee for Clinical Laboratory Standards; 2018. 92p.

[16] Flanagan D. Enterococcus faecalis and Dental Implants. J Oral Implantol [Internet]. 2017; 43(1):8-11. Available from: https://doi.org/10.1563/aaid-joi-D-16-00069

[17] Prad I, Micó-Muñoz P, Giner-Lluesma T, Collado-Castellano N, Manzano-Saiz A. Influence of microbiology of endodontic failure. Literature review. Med Oral [Internet]. 2019;24(3):e364-72. Available from: https://doi.org/10.4317/medoral.22907

[18] Halkai R, Hedge MN, Halkai K. Evaluation of the presence of Enterococcus Faecalis in root cementum: A confocal laser scanning microscope analysis. J Conserv Dent [Internet]. 2014;17(2):119-23. Available from: https://doi.org/10.4103/0972-0707.128039 